The Grecanici of Southern Italy 



\section{The Grecanici of Southern Italy}

Governance, Violence, and Minority Politics

Stavroula Pipyrou

\section{$\overline{\text { PENN }}$}

UNIVERSITY OF PENNSYLVANIA PRESS

PHILADELPHIA 
Copyright $\odot 2016$ University of Pennsylvania Press

All rights reserved. Except for brief quotations used for purposes of review or scholarly citation, none of this book may be reproduced in any form by any means without written permission from the publisher.

Published by

University of Pennsylvania Press

Philadelphia, Pennsylvania 19104-4112

www.upenn.edu/pennpress

Printed in the United States of America on acid-free paper

$\begin{array}{llllllllll}10 & 9 & 8 & 7 & 6 & 5 & 4 & 3 & 2 & 1\end{array}$

Library of Congress Cataloging-in-Publication Data

ISBN 978-0-8122-4830-2 
This book is dedicated to my mother Eleni and stepfather Giorgo 
